\title{
Characteristics of the Infection of Tilletia laevis Kühn (syn. Tilletia foetida (Wallr.) Liro.) in Compatible Wheat
}

\author{
Zhaoyu Ren $^{1 \dagger}$, Wei Zhang ${ }^{1,2 \dagger}$, Mengke Wang ${ }^{1,2 \dagger}$, Haifeng Gao ${ }^{3}$, Huimin Shen ${ }^{1}$, Chunping Wang ${ }^{2}$, Taiguo Liu ${ }^{1}$, \\ Wanquan Chen ${ }^{1}$, and $\mathrm{Li} \mathrm{Gao}{ }^{1 *}$ \\ ${ }^{1}$ State Key Laboratory for Biology of Plant Disease and Insect Pests, Institute of Plant Protection, Chinese Academy of \\ Agricultural Sciences, Beijing 100193, China \\ ${ }^{2}$ College of Agronomy, Henan University of Science and Technology, Henan 471023, China \\ ${ }^{3}$ Institute of Plant Protection, Xinjiang Academy of Agricultural Sciences, Key Laboratory of Integrated Pest Manage- \\ ment on Crop in Northwestern Oasis, Ministry of Agriculture and Rural Affairs, Urumqi 830091, China
}

(Received on May 27, 2021; Revised on July 25, 2021; Accepted on July 26, 2021)

Tilletia laevis Kühn (syn. Tilletia foetida (Wallr.) Liro.) causes wheat common bunt, which is one of the most devastating plant diseases in the world. Common bunt can result in a reduction of $80 \%$ or even a total loss of wheat production. In this study, the characteristics of $T$. laevis infection in compatible wheat plants were defined based on the combination of scanning electron microscopy, transmission electron microscopy and laser scanning confocal microscopy. We found $T$. laevis could lead to the abnormal growth of wheat tissues and cells, such as leakage of chloroplasts, deformities, disordered arrangements of mesophyll cells and also thickening of the cell wall of mesophyll cells in leaf tissue. What's more, T. laevis teliospores were found in the roots, stems, flag leaves, and glumes of infected wheat plants instead of just in the ovaries, as previously reported. The abnormal characteristics caused by $T$. laevis may be used for early detection of this pathogen instead of molecular markers in addition to providing theoretical insights into $T$. laevis and wheat interactions for breeding of common bunt resistance.

\footnotetext{
${ }^{\dagger}$ These authors contributed equally to this work.

*Corresponding author.

Phone) +86-10-62815618, FAX) +86-10-62815618

E-mail)xiaogaosx@hotmail.com
}

Handling Editor : Junhyun Jeon

(c) This is an Open Access article distributed under the terms of the Creative Commons Attribution Non-Commercial License (http:// creativecommons.org/licenses/by-nc/4.0) which permits unrestricted noncommercial use, distribution, and reproduction in any medium, provided the original work is properly cited.

Articles can be freely viewed online at www.ppjonline.org.
Keywords : laser scanning confocal microscopy, scanning electron microscopy, Tilletia laevis Kühn, transmission electron microscopy, wheat common bunt

Common bunt of wheat is a very severe disease characterized by a wide distribution, strong epidemic potential, and serious damage (Gaudet et al., 2007). The infected plants usually have no special symptoms that are easily seen. During the late stage of common bunt, glumes tend to spread apart slightly. The whole wheat ear becomes diseased. Wheat grains are coated with a layer of gray-brown film and filled with black powder, which are the teliospores of the pathogen. These teliospores of the pathogen Tilletia laevis Kühn (syn. Tilletia foetida (Wallr.) Liro.) can produce fishlike smells and cause reductions in wheat yield and quality (Goates, 2012; Singh et al., 2016). Common bunt of wheat frequently occurs in northern China, where the pathogen spreads with wheat seeds and can survive in the soil for many years. Previous studies on common bunt of wheat have mainly focused on identifying the biological characteristics of the pathogen and developing detection methods (Pieczul et al., 2018; Yao et al., 2019). Morphology, germination characteristics and karyotype analysis are the basis of teliospore identification and classification (Russell and Mills, 1993).

Pathogen infection can cause changes in the cellular and subcellular structures of plants. Electron microscopy is an important tool for observing cell structural changes and the morphology and structure of pathogens. With the development of this method, electron microscopy has been increasingly applied to study plant diseases. Compared with opti- 
cal microscopy, scanning electron microscopy can provide a higher resolution and be used to observe the fine morphological characteristics of the sample surface. This technique has been applied to study pathogenic mechanisms, such as those of Leveillula taurica, Alternaria solani, and Beauveria bassiana (Li et al., 2016; Zhang et al., 2020; Zheng et al., 2013). Transmission electron microscopy has been used to study the inhibitory effect of rice endophyte Streptomyces on rice blast pathogen (Xu et al., 2019) and the interaction of hydroxycoumarins and Ralstonia solanacearum in plants (Yang et al., 2016).

Laser scanning confocal microscopy is based on fluorescence microscopy and employs a laser scanning device. This method uses UV or visible light to excite fluorescent probes and a computer to process the images and can reveal the fine internal structures of cells or tissues. Therefore, laser scanning confocal microscopy is a powerful tool for the research of molecular cell biology, genetics, immunology, and pathology (Muhae-Ud-Din et al., 2020). It can be used to observe the cellular morphological changes in host tissues after pathogen infection and study the infection of pathogens and the interactions between pathogens and hosts (Xu et al., 2021). Gao et al. (2013) used laser scanning confocal microscopy to investigate the impact of corn smut pathogen on maize anther development. Investigating the infection of $T$. laevis will help to reveal the pathogenesis of common bunt and the interactions between pathogen and the host and is thus important for preventing, controlling, and breeding resistance to common bunt of wheat.

In the study of the ultrastructures involved in wheat bunt infection (Woolman, 1930), reported the initial stage of $T$. controversa infection in wheat and divided it into three stages according to the hyphal transition from gram-negative to positive. Woolman found that the hyphal infection of the epidermal cells causes the thicken of epidermal cell wall. It was confirmed that the change in the fungus from gram-negative to gram-positive occurred simultaneously with the establishment of the parasitic relationship between the fungus and the host. Hansen (1959) conducted anatomical studies on wheat ears and seedlings infected with dwarf bunt, rye smut, common bunt and found that the process of infecting the injured seedlings with the mycelia of the three fungi was similar; these researchers described the developmental process of fungal mycelium from host plant inoculation to spore formation in detailed. All the above studies only used light microscopy and section dyeing methods to observe the ultrastructures of the plants, and there has been no detailed description of infection with hyphae over specific growth stages of wheat plants. This study clearly defined the characteristics of $T$. laevis infection based on the use of optical microscopy, scanning electron microscopy, transmission electron microscopy, and laser scanning confocal microscopy instead of only sectioning. Moreover, this study focused on key periods of wheat growth, including the one-leaf (Z11), two-leaf (Z12), three-leaf (Z13), tillering (Z21), jointing (Z31), and mature stages (Z92) (Zadoks et al., 1974), instead of only certain stages used in previous reports.

\section{Materials and Methods}

Germination of the teliospores of T. laevis. T. laevis was provided by the Institute of Plant Protection, Chinese Academy of Agricultural Sciences. The teliospores (100 $\times$ $\left.10^{4}-10^{5} \times 10^{4} / \mathrm{ml}\right)$ were cultured in $2 \%$ water agar medium according to a previously described culture method for common bunt pathogen (Yao et al., 2019) and then were cultured in an incubator (LT-36 VLC8, SANYANG, Percival, Fremont, IW, USA) at $16^{\circ} \mathrm{C}$ with $24 \mathrm{~h}$ of light for 3 days and observed under an inverted microscope (IX83, Olympus, Tokyo, Japan). The observation was carried out every $12 \mathrm{~h}$. The infection hyphae were collected on the

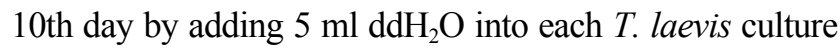
plate. The suspension used for inoculation contained infectious hyphae at a concentration of $10^{6} \mathrm{cfu} / \mathrm{ml}$ with $\mathrm{OD}_{600}$ of 0.15 .

Plant culture and T. laevis inoculation. The winter wheat variety Dongxuan 3 was used in this study. The seeds were obtained from the Institute of Plant Protection, Chinese Academy of Agricultural Sciences. The seeds were washed and soaked for $24 \mathrm{~h}$, and the surface of the seeds was sterilized with $30 \% \mathrm{NaClO}$ for $1 \mathrm{~min}$ and washed three times with $\mathrm{ddH}_{2} \mathrm{O}$ for disinfection. The seed surface was covered with a layer of moist gauze and incubated at $5^{\circ} \mathrm{C}$ for 4 weeks in the dark. When the wheat germ sheath grew to 1-3 cm (at the germination stage (Z09), the seedlings were moved into a pot filled with a mixture of organic matter and soil at a ratio of $1: 2 \%$ and placed in a plant incubator (LT-36 VLC8, Percival). In the seedling growth stage (Z11), hyphal suspension was injected into the soil in which the seedlings were growing. The soil surrounding each seedling was injected with $2 \mathrm{ml}$ of suspension every $12 \mathrm{~h}$ for a total of 10 injections. The mock was injected with $\mathrm{ddH}_{2} \mathrm{O}$ under the same growth conditions.

Detection of T. laevis in plants. DNA was extracted from wheat leaves after $T$. laevis inoculation using a plant genomic DNA extraction kit (TianGen, Beijing, China). Two treatments, infected wheat plants and mock inocula- 
tion, were set up, and each treatment included 30 wheat plants. The specific $T$. laevis sequence was amplified by the specific primer (SCAR) L60F: 5'-TCACTTCAAGGTCGTTCCCG-3', L60R: 5'-GTCGAGGGGCGTAAACTTGA-3'. The amplification reaction was performed in a 25 $\mu \mathrm{l}$ mixture: $12.5 \mu \mathrm{l}$ of $2 \times$ EasyTaq PCR SuperMix (+dye) (TransGen Biotech, Beijing, China), $9.5 \mu \mathrm{l}$ of $\mathrm{ddH}_{2} \mathrm{O}, 1$ $\mu \mathrm{l}$ of DNA template $(100 \mathrm{ng}), 1 \mu \mathrm{l}$ of the primer L60F $(10 \mu \mathrm{M})$, and $1 \mu \mathrm{l}$ of the primer L60R $(10 \mu \mathrm{M})$. The PCR amplification procedure was as follows: $94^{\circ} \mathrm{C}$ high temperature denaturation for $30 \mathrm{~min}, 30$ amplification cycles including $94^{\circ} \mathrm{C}$ high temperature denaturation for $30 \mathrm{~s}$, $57^{\circ} \mathrm{C}$ annealing for $30 \mathrm{~s}, 72^{\circ} \mathrm{C}$ extension for $45 \mathrm{~s}$, and finally $72^{\circ} \mathrm{C}$ extension for $10 \mathrm{~min}$. The detection of a 660 bp positive amplification band was considered a successful infection (Yao et al., 2019).

Sample preparation for scanning electron microscopy. Based on the protocols used by Xu et al. (2021), we modified with the following details; three infected wheat leaves and three mock inoculated leaves in each stage were used, for each stage of the one-leaf (Z11), two-leaf (Z12), threeleaf (Z13), tillering (Z21), jointing (Z31), and mature stages (92), 10 samples were used for scanning electron microscopy observation. For the mature stage samples, we also checked the roots, stems, leaves, glumes and awns of the infected wheat. The surfaces of the plant tissues were cleaned, cut into small pieces with a blade, immediately placed in a 3\% glutaraldehyde solution for $48 \mathrm{~h}$, and then washed with phosphate buffer. Samples were dehydrated with $30 \%, 40 \%, 50 \%, 60 \%, 70 \%, 80 \%, 90 \%, 95 \%$, and $100 \%$ ethanol in sequence, and each dehydration time was more than $20 \mathrm{~min}$. A desiccator (Leica CPD 030, Wetzlar, Germany) was used to dry the samples, which were placed on a copper table with double-sided conductive tape paper, and gold was sprayed onto the sample surface for observation with a scanning electron microscope (S-570, HITACHI, Tokyo, Japan).

Sample preparation for transmission electron microscopy. The samples were chosen as the same method mentioned for scanning electron microscopy. We followed the protocol published previously by Xu et al. (2021), briefly; the surface of the plant tissue was cleaned, cut it into small pieces with a blade, and immediately put in a $3 \%$ glutaraldehyde solution for $48 \mathrm{~h}$, and a vacuum was used to remove the bubbles in the plant tissue. With this method, when the plant sample sinks, the glutaraldehyde is completely infiltrated into the plant tissues. The residues on the sample surface were washed with plant buffer. Samples were dehydrated with $30 \%, 40 \%, 50 \%, 60 \%, 70 \%, 80 \%$, $90 \%, 95 \%$, and $100 \%$ ethanol in sequence, and each dehydration time was more than $20 \mathrm{~min}$. The samples were treated with $1 \%$ osmium acid to make the samples turn black and then rinsed with acetone solution for $1 \mathrm{~h}$. After rinsing, an appropriate amount of epoxy resin was added to embed and polymerize the samples, and they were then processed with an ultrathin microtome, stained with uranium acetate and lead citrate, and observed with a transmission electron microscope (H-7650, HITACHI).

Sample preparation for laser scanning confocal microscopy. These samples were prepared as mentioned for scanning electron microscopy, and then were stained using a solution containing $10 \mu \mathrm{g} / \mathrm{ml}$ propidium iodide (Life Technologies, Carlsbad, CA, USA), $0.02 \%$ Tween-20, and $20 \mu \mathrm{g} / \mathrm{ml} \mathrm{WGA-AF} 488$ (Life Technologies) for 30-60 min and rinsed with $1 \times$ PBS (pH 7.4) 3-5 times (Kelliher and Walbot, 2011; Muhae-Ud-Din et al., 2020). The prepared samples were then placed on glass slides and observed under a laser scanning confocal microscope (SP8, Leica). The excitation wavelength for WGA-AF 488 was $488 \mathrm{~nm}$, and the emission wavelength was $510-550 \mathrm{~nm}$. The excitation wavelength for propidium iodide (PI) was $561 \mathrm{~nm}$, and the emission wavelength was $570-730 \mathrm{~nm}$.

\section{Results}

Inoculation and detection of T. laevis. T. laevis teliospores were cultured in an incubator at $16^{\circ} \mathrm{C}$ and germinated 3 days later (Fig. 1A). After 7 days of culture, most teliospores had grown infectious hyphae (Fig. 1B). The hyphae were collected on the 10th day and used for artificial inoculation (Fig. 1C). Wheat growth and common bunt development were observed in different periods after artificial inoculation. The infected wheat plants usually had no obvious symptoms at the seedling stage. During the maturation stage, the glumes of infected wheat plants tended to spread apart slightly, and the whole wheat ear became dark (Fig. 1D-F). Wheat grains were filled with black powder, which were the teliospores of T. laevis, and produced fishlike smell. We took the leaves from inoculated plants and then ran PCR to detect the successful infection of T. laevis with a specific 660 -bp positive amplification band (Supplementary Fig. 1) (Yao et al., 2019).

Characteristics observed by scanning electron microscopy. After the successful infection of the pathogen were confirmed by molecular detection, the leaf tissues at different growth stages were observed with scanning electron 

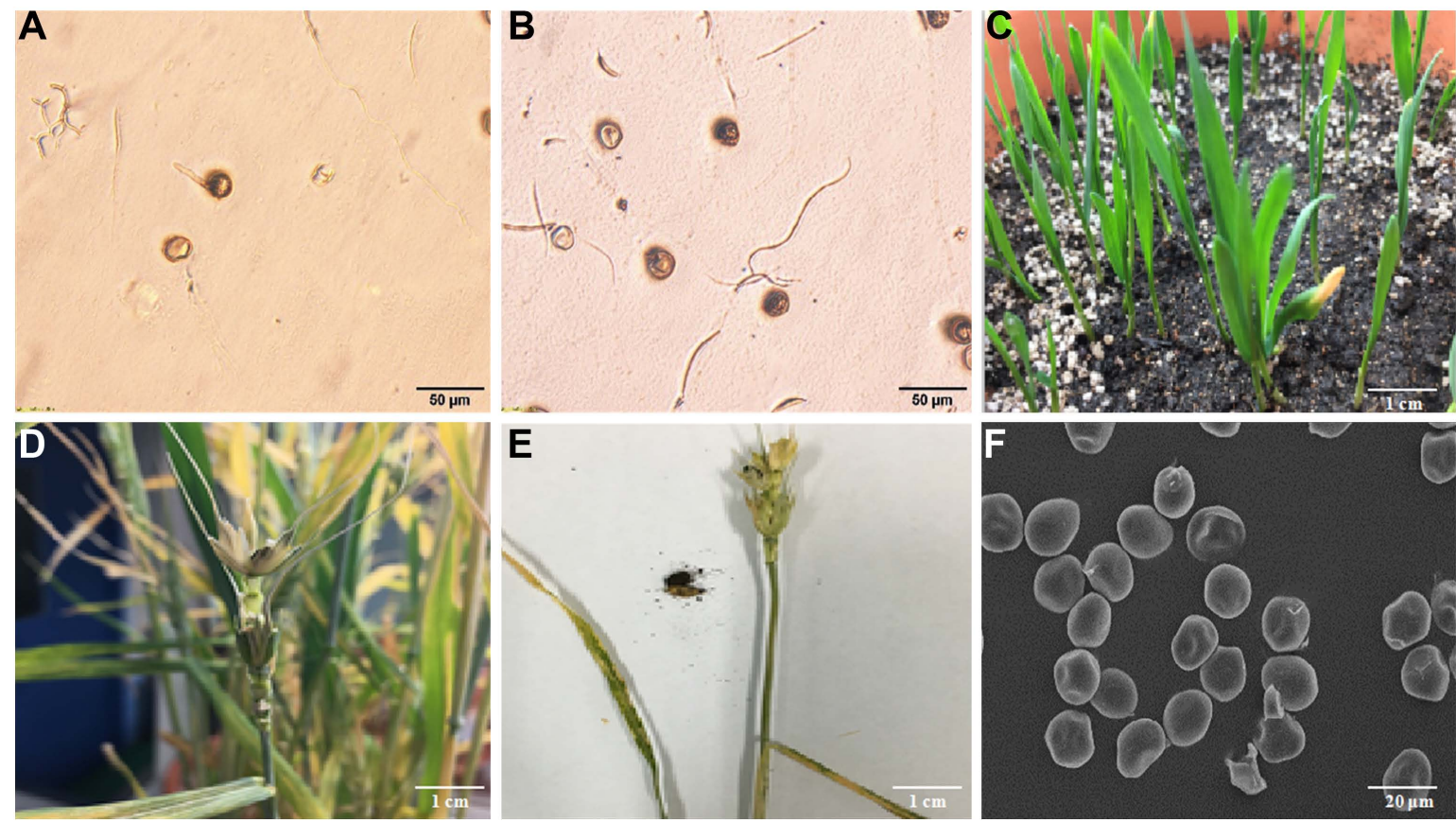

Fig. 1. Schematic diagrams of Tilletia laevis infection process. (A) The primary hyphae growing from teliospores after germination. (B) Infectious hyphae. (C) Wheat seedlings after artificial inoculation. (D) During the mature stage, wheat glumes spread apart, and the spikelets were transformed into bunt balls. (E) When the seed coat was stripped off, the seeds were full of teliospores. (F) The teliospores of pathogens observed under scanning electron microscopy.

microscope. The results showed that the cellular ultrastructure in infected wheat plants showed big differences compared with that of the mock. In the mock of wheat leaf tissue, the chloroplasts were arranged orderly in mesophyll cells (Fig. 2A-C). However, different degrees of malformation were observed in mesophyll cells in the one-leaf $(Z 11)$, two-leaf (Z12), three-leaf (Z13), tillering (Z21), and jointing (Z31) stages. At the one-leaf stage, hyphae invaded wheat roots and spread to leaves where they did not cause much deformation because of little hyphae (Fig. 2D). However, with the increase in hyphae during later stages, the impaction to the host became severe. At the two-leaf stage, severe cell deformation around the sieve tubes were found (Fig. 2E). At the three-leaf stage, the membrane of mesophyll cells ruptured (Fig. 2F). At the tillering stage, mesophyll cells deformed and plasma membranes were broken (Fig. 2G). At the jointing stage, the plasma membranes of mesophyll cells were broken, and leaf chloroplasts were no longer closely arranged in a single layer but were scattered throughout or emerged from the cells (Fig. 2H). In addition, at the mature stage, we found teliospores of $T$. laevis in the images (Fig. 2I). We also checked the roots, stems, leaves, glumes, and awns of infected mature wheat plants and found a large number of $T$. laevis teliospores in these tissues (Fig. 3).
Characteristics observed by transmission electron microscopy. Transmission electron microscopy was used to observe mock and infected wheat plants. In mock wheat tissue, root and leaf cells were regularly arranged (Supplementary Fig. 2A, C), chloroplasts were closely arranged along the lateral side of the cell (Supplementary Fig. 2E), the layer structure was clear, and there was no accumulation of impurities, and an intact cellular structure was observed in the sieve tube cell (Supplementary Fig. 2G). In infected tissues, the arrangement of root cells became looser (Supplementary Fig. 2B), the boundaries between adjacent cells were unclear, and cells showed obvious deformation in leaf (Supplementary Fig. 2D), some chloroplasts were deformed and the chloroplast layer became blurred in leaf (Supplementary Fig. 2F), cell morphology was changed, and the accumulation of impurities was observed in sieve tube cells (Supplementary Fig. 2H).

At the mature stage, hyphae were observed in leaf blades, stems, leaf sheaths, and glumes (Fig. 4). Hyphae accumulated in the mesophyll cells, and the cell walls of mesophyll cells were thicker than those of normal cells in leaves (Fig. 4A). There were a large number of hyphae in the sieve tubes and companion cells, and some cells were deformed in stems (Fig. 4B). The leaf sheaths and glumes were also found to have hyphae that deformed the normal cells in 


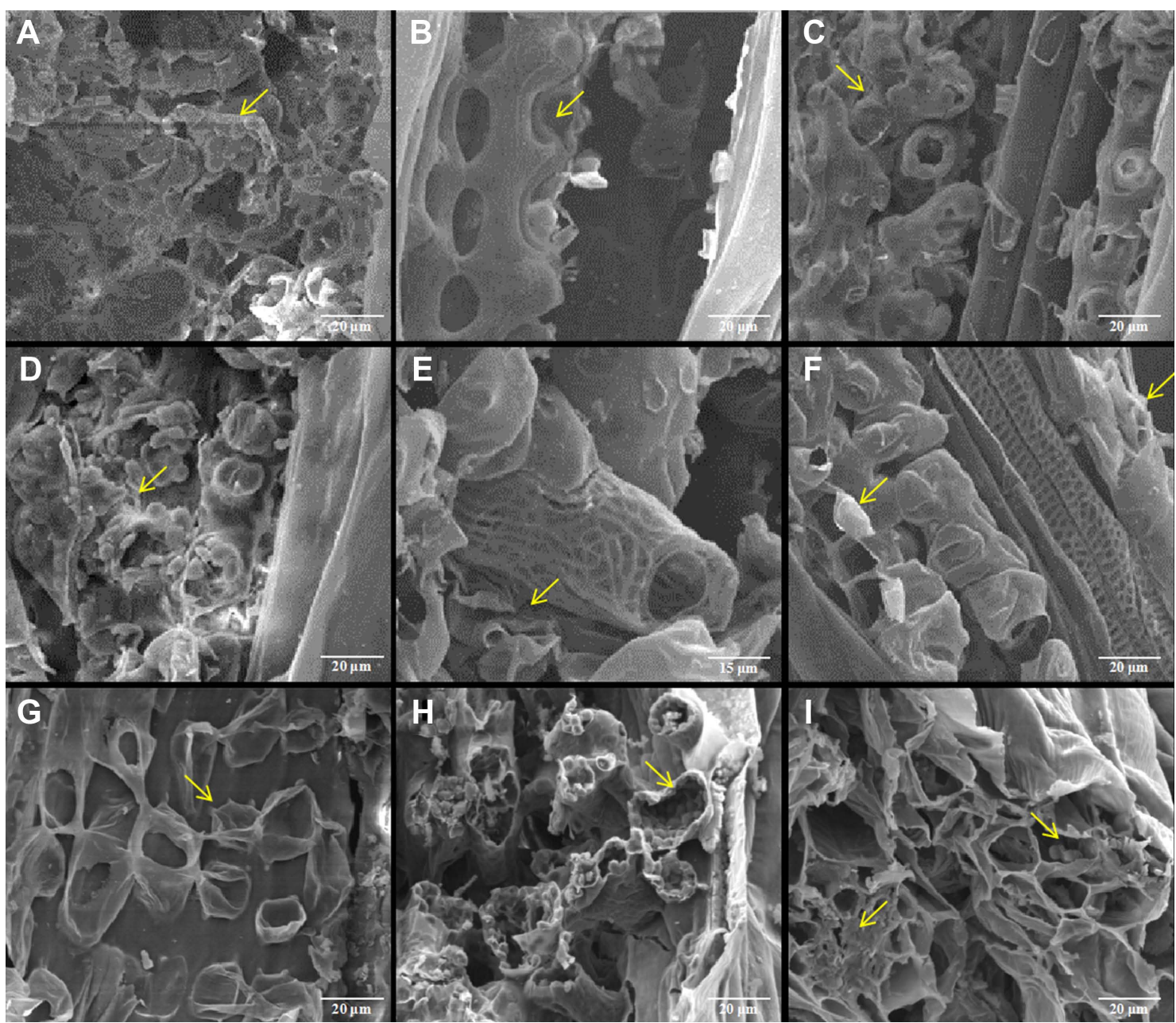

Fig. 2. Infection of wheat leaves by Tilletia laevis observed with scanning electron microscopy. (A) Mock wheat tissues at the one-leaf (Z11) stage. Chloroplasts were closely arranged in mesophyll cells. The arrow indicates chloroplasts. (B) Mock wheat tissues at the twoleaf (Z12) stage. The arrow indicates a normal cell. (C) Mock wheat tissues at the three-leaf (Z13) stage. The arrow indicates a cell with normal morphology. (D) Infected wheat plant at the one-leaf (Z11) stage. The arrow indicates the deformed cell. (E) Infected wheat plant at the two-leaf (Z12) stage. Severe cell deformation around the sieve tube. The arrow indicates a deformed cell. (F) Infected wheat plant at the three-leaf (Z13) stage. The structures of mesophyll cells were changed, and the cell membrane ruptured. The two arrows indicate deformed cells. (G) Infected wheat plant at the tillering (Z21) stage. Deformed cells with broken plasma membranes. The arrow indicates a deformed cell. $(\mathrm{H})$ Infected wheat plant at the shooting (Z31) stage. Chloroplasts emerging from the cell. The arrow indicates a damaged chloroplast. (I) Infected wheat plant at the mature stage (92). Deformation of differentiated vascular bundles. The left arrow indicates vascular bundles, and the right arrow indicates scattering chloroplasts.

both tissues (Fig. 4C and D).

Characteristics observed by laser scanning confocal microscopy during the infection process. Laser scanning confocal microscopy was used to observe the distribution of hyphae in T. laevis-infected wheat tissues at different growth stages. In infected wheat plants, hyphae were observed in root tissues (Fig. 5A-C). Hyphae were also found in plant tissues in the one-leaf (Z11), two-leaf (Z12), threeleaf (Z13), tillering (Z21), and jointing stages (Z31). With the growth of wheat plants, an increase in mycelia in the leaves was found (Fig. 5D-R). After the invasion of wheat roots by $T$. laevis, hyphae were found to spread to the anthers (Fig. 5S-X).

\section{Discussion}

In this study, we used scanning electron microscopy, transmission electron microscopy, and laser scanning confocal microscopy to characterize the infection process of $T$. lae- 


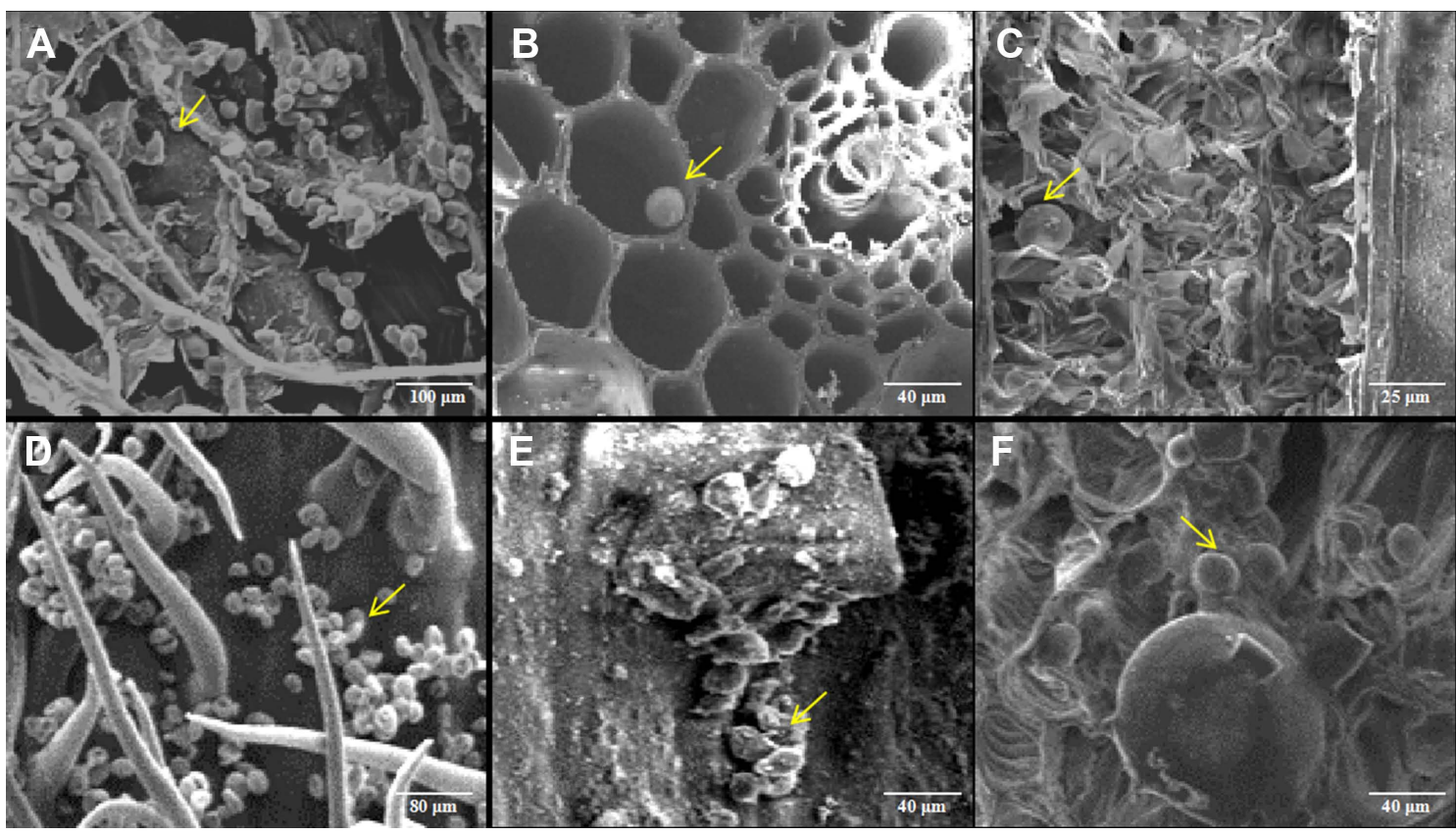

Fig. 3. The roots, stems, leaves, glumes, awns and grains of Tilletia laevis-infected wheat plants were observed by scanning electron microscopy at the mature stage. (A) T. laevis-infected wheat roots. A large number of teliospores were present in the lateral roots during the mature stage. The arrow indicates teliospores in wheat roots. (B) T. laevis-infected wheat stems. The arrow indicates teliospores inside wheat stems. (C) Teliospores in T. laevis-infected wheat flag leaves. The arrow indicates a teliospore. (D) A large number of teliospores on the inner surface of infected wheat glumes. The arrow indicates a teliospore. (E) A large number of teliospores in infected awns. The arrow indicates aggregated teliospores. (F) A grain containing teliospores of T. laevis. The arrow indicates teliospores of $T$. laevis.

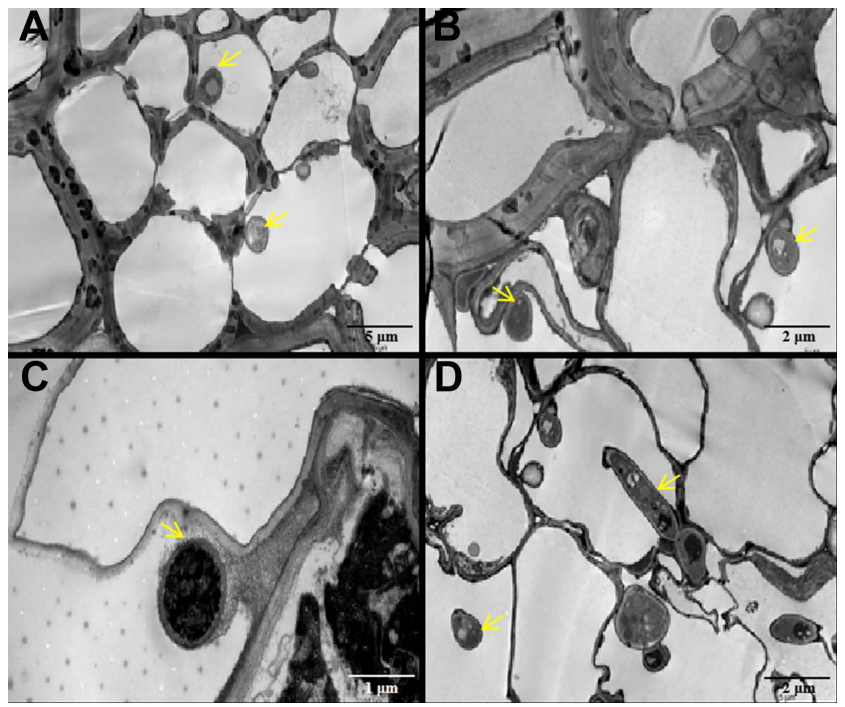

Fig. 4. Tilletia laevis-infected wheat leaves, stems, leaf sheaths, and glumes observed by transmission electron microscopy at the mature stage. (A) The infected wheat leaf tissues. The arrows indicate hyphae inside the cell $(\times 4,000)$. (B) T. laevis-infected wheat stems. Deformed cells and irregular cell morphology. The arrows indicate the hyphae $(\times 5,000)$. (C) The mycelium in leaf sheaths. The arrow indicates the hyphae $(\times 15,000)$. (D) Hyphae appeared in the wheat glumes infected by T. laevis. The arrow on the left indicates the hyphae, and the arrow on the right indicates the spread of hyphae between adjacent cells $(\times 4,000)$. vis in compatible wheat plants. Scanning electron microscopy could be used to observe the teliospores in wheat tissues, and transmission electron microscopy could be used to directly observe the distribution of pathogens in plant tissues, organs and the ultrastructural changes caused by the infection of the pathogen. Particularly, we used WGAAF 488 to label T. laevis hyphae and used PI to label wheat tissues with laser scanning confocal microscopy, which was much simpler and produced clearer results than using the traditional tissue sectioning technique (Xu et al., 2021).

Based on the successful inoculation system of T. laevis (Fig. 1), we defined T. laevis in wheat leaves, roots, stems, glumes, etc. at the one-leaf (Z11), two-leaf (Z12), threeleaf (Z13), tillering (Z21), and jointing (Z31) stages of infected wheat plants. With the invasion of hyphae, we found that mesophyll cells were deformed, and finally, the plasma membrane was broken in wheat leaves (Fig. 2), and a large number of teliospores were discovered in the roots, stems, leaves, glumes, and awns of infected wheat plants with scanning microscopy (Fig. 3). Gaudet et al. (2007) reported that $T$. tritici invaded the wheat germ sheaths, the middle lamella between epidermal cells was dissolved during penetration, and with the prolongation of time, the cells surrounding the hyphae also produced corpus callosum. 


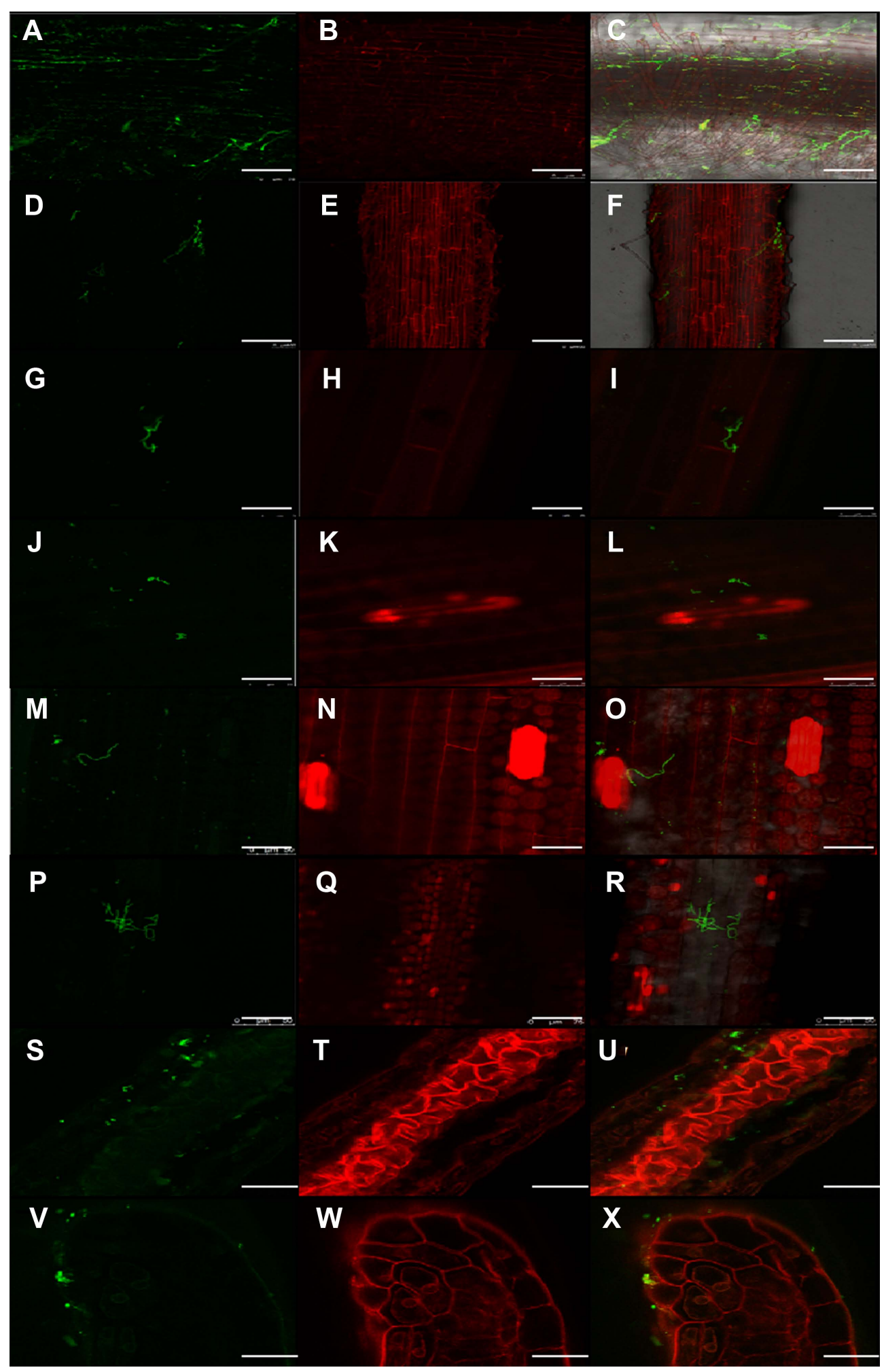

Fig. 5. Tilletia laevis-infected wheat roots, stems, and anthers observed by laser scanning confocal microscopy at different stages of wheat growth. Hyphae were stained by WGA-488 (green), and wheat tissues were stained by PI (red). (A-C) Hyphae were observed at wheat roots after inoculation with T. laevis. (D-F) A leaf blade infected by T. laevis at the one-leaf (Z11) stage. (G-I) A leaf blade infected by T. laevis at the two-leaf (Z12) stage. (J-L) A leaf blade infected by T. laevis at the three-leaf (Z13) stage. (M-O) A leaf blade infected by $T$. laevis at the tillering (Z21) stage. (P-R) A leaf blade infected by T. laevis at the shooting (Z31) stage. (S-U) The anther tissues infected by T. laevis at $800 \mu \mathrm{m}$. (V-X) The anther tissues infected by T. laevis at $900 \mu \mathrm{m}$. Scale bars $=50 \mu \mathrm{m}$. 
In susceptible wheat and barley infected with barley yellow dwarf virus-PAV, the sieve elements and companion cells in the phloem tissue were severely deformed (Choudhury et al., 2018) and we found similar characteristics in our study (Figs. 2, 4). The chloroplast is one of the most important organelles in plant cells, and it is the center of energy conversion and the energy source for plant cells. Through transmission electron microscopy and scanning electron microscopy, we found that $T$. laevis infection can cause a disordered chloroplast arrangement in mesophyll cells and some chloroplast cells were deformed (Fig. 2, Supplementary Fig. 2). There was a similar phenomenon in wheat infected with Puccinia striiformis f. sp. tritici and Mycosphaerella graminicola (Hafez et al., 2020; Kema et al., 1996). The root is an important organ of the plant, and the invasion of pathogenic fungi will also cause changes in the ultrastructure of the root cells. The root cells separate from the wall, and the mitochondria vacuolate when Phytophthora sojae infects the roots of susceptible soybeans. In our study, transmission electron microscopy found that the root cells infected by the hyphae were also deformed, and impurities accumulated inside (Supplementary Fig. 2). Thus, infection by $T$. laevis can induce abnormal in wheat cells (Fig. 4).

The anther is the key part determining the impact of common bunt of wheat. The incidence of common bunt may be different even on different anthers of the same spikelet. The infection of maize anthers by Ustilago maydis can result in abnormal differentiation of anther cells and delayed anther development, which will affect normal fertilization (Gao et al., 2013). We also found hyphae in wheat anthers (Fig. 5) with laser scanning confocal microscopy, and we will continue to study the impacts of $T$. laevis infection on wheat anther development in our follow-up studies. Investigating the characteristics of pathogenic infection can help to further our understanding of pathogenic mechanisms, provide a theoretical basis for related research, and improve the prevention and control of plant diseases.

Conclusions. T. laevis invaded the roots of wheat after the germination of wheat seeds in the soil, causing ultrastructural changes in wheat tissues and cells to different degrees. With the increase in hyphae in the later period, the impaction to the wheat tissue also increased; for example, a large number of cells were deformed in the roots and leaves, and a large number of hyphae and teliospores were found at the mature stage in different tissues, including leaves, stems, leaf sheaths, glumes and even anthers of wheat, which was not mentioned in previous reports. Characterizing the infection of $T$. laevis can provide theoretical insights into $T$. laevis-wheat interactions and breeding for common bunt resistance.

\section{Conflicts of Interest}

No potential conflict of interest relevant to this article was reported.

\section{Acknowledgments}

This work was supported by the National Natural Science Foundation of China (31761143011), and Chinese Ministry of Agriculture (CARS-03). Each of the funding bodies granted the funds on the basis of a research proposal. The bodies had no influence on the experimental design, data analysis and interpretation, or writing of the manuscript.

\section{Electronic Supplementary Material}

Supplementary materials are available at The Plant Pathology Journal website (http://www.ppjonline.org/).

\section{References}

Choudhury, S., Hu, H., Larkin, P., Meinke, H., Shabala, S., Ahmed, I. and Zhou, M. 2018. Agronomical, biochemical and histological response of resistant and susceptible wheat and barley under BYDV stress. PeerJ 6:e4833.

Gao, L., Kelliher, T., Nguyen, L. and Walbot, V. 2013. Ustilago maydis reprograms cell proliferation in maize anthers. Plant $J$. 75:903-914.

Gaudet, D. A., Lu, Z.-X., Leggett, F., Puchalski, B. and Laroche, A. 2007. Compatible and incompatible interactions in wheat involving the Bt-10 gene for resistance to Tilletia tritici, the common bunt pathogen. Phytopathology 97:1397-1405.

Goates, B. J. 2012. Identification of new pathogenic races of common bunt and dwarf bunt fungi, and evaluation of known races using an expanded set of differential wheat lines. Plant Dis. 96:361-369.

Hafez, Y. M., Mourad, R. Y., Nasr, E. B., Attia, K., Abdelaal, K. A., Ghazy, A. I., Al-Ateeq, T. K., Ibrahim, E. I. and Mohammed, A. A. 2020. Biochemical and molecular characterization of non-host resistance keys in food crops. Saudi J. Biol. Sci. 27:1091-1099.

Hansen, F. 1959. Anatomische untersuchungen uber eindringen und ausbreitung von Tilletia-arten in getreidepflanzen in abhängigkeit vom entwicklungszustand der wirtspflanze. $J$. Phytopathol. 34:169-208 (in German).

Kelliher, T. and Walbot, V. 2011. Emergence and patterning of the five cell types of the Zea mays anther locule. Dev. Biol. 350:32-49.

Kema, G. H. J., Yu, D., Rijkenberg, F. H. J., Shaw, M. W. and 
Baayen, R. 1996. Histology of pathogenesis of Mycosphaerella graminicola in wheat. Phytopathology 86:777-786.

Li, J., Guo, Q., Lin, M., Jiang, L., Ye, J., Chen, D., Li, Z., Dai, J. and Han, S. 2016. Evaluation of a new entomopathogenic strain of Beauveria bassiana and a new field delivery method against Solenopsis invicta. PLoS ONE 11:e0158325.

Muhae-Ud-Din, G., Chen, D., Liu, T., Chen, W. and Gao, L. 2020. Characterization of the wheat cultivars against Tilletia controversa Kühn, causal agent of wheat dwarf bunt. Sci. Rep. 10:9029.

Pieczul, K., Perek, A. and Kubiak, K. 2018. Detection of Tilletia caries, Tilletia laevis and Tilletia controversa wheat grain contamination using loop-mediated isothermal DNA amplification (LAMP). J. Microbiol. Methods 154:141-146.

Russell, B. W. and Mills, D. 1993. Electrophoretic karyotypes of Tilletia caries, T. controversa, and their F1 progeny: further evidence for conspecific status. Mol. Plant-Microbe Interact. 6:66-74.

Singh, A., Knox, R. E., DePauw, R. M., Singh, A. K., Cuthbert, R. D., Kumar, S. and Campbell, H. L. 2016. Genetic mapping of common bunt resistance and plant height QTL in wheat. Theor. Appl. Genet. 129:243-256.

Woolman, H. M. 1930. Infection phenomena and host reactions caused by Tilletia tritici in susceptible and non-susceptible varieties of wheat. Phytopathology 20:637-652.

Xu, T., Cao, L., Zeng, J., Franco, C., Yang, Y., Hu, X., Liu, Y., Wang, X., Gao, Y., Bu, Z., Shi, L., Zhou, G., Zhou, Q., Liu,
X. and Zhu, Y. 2019. The antifungal action mode of the rice endophyte Streptomyces hygroscopicus OsiSh-2 as a potential biocontrol agent against the rice blast pathogen. Pestic. Biochem. Physiol. 160:58-69.

Xu, T., Qin, D., Muhae Ud Din, G., Liu, T., Chen, W. and Gao, L. 2021. Characterization of histological changes at the tillering stage (Z21) in resistant and susceptible wheat plants infected by Tilletia controversa Kühn. BMC Plant Biol. 21:49.

Yang, L., Ding, W., Xu, Y., Wu, D., Li, S., Chen, J. and Guo, B. 2016. New insights into the antibacterial activity of hydroxycoumarins against Ralstonia solanacearum. Molecules 21:468.

Yao, Z., Qin, D., Chen, D., Liu, C., Chen, W., Liu, T., Liu, B. and Gao, L. 2019. Development of ISSR-derived SCAR marker and SYBR green I real-time PCR method for detection of teliospores of Tilletia laevis Kühn. Sci. Rep. 9:17651.

Zadoks, J. C., Chang, T. T. and Konzak, C. F. 1974. A decimal code for the growth stages of cereals. Weed Res. 14:415-421.

Zhang, D., Yu, S., Yang, Y., Zhang, J., Zhao, D., Pan, Y., Fan, S., Yang, Z. and Zhu, J. 2020. Antifungal effects of volatiles produced by Bacillus subtilis against Alternaria solani in potato. Front. Microbiol. 11:1196.

Zheng, Z., Nonomura, T., Bóka, K., Matsuda, Y., Visser, R. G. F., Toyoda, H., Kiss, L. and Bai, Y. 2013. Detection and quantification of Leveillula taurica growth in pepper leaves. Phytopathology 103:623-632. 